\title{
Application \& Research on Foundation Stabilization Structure during Work Progress of Civil Engineering
}

\author{
Guochao $\mathrm{Lu}^{*}$ \\ College of Municipal and Bridge Engineering, Inner Mongolia Technical College of Construction, Inner Mongolia \\ 0100704, China
}

\begin{abstract}
To study the method about structure layer of geocell reinforced with macadam, as well as effectiveness and practicality of such a method in foundation reinforcement during work progress of civil engineering; Method: Basic theory and method about foundation reinforcement structure applied in work process of civil engineering have been studied. Physical model of experimental tank built by loaded plates has been established. Experiments have been conducted on the loaded-plate tank for geocells in different specification and filler in the geocell to determine the relationship between loads at various structure layers and longitudinal travel. Experimental results showed that structure layer of geocell reinforced with macadam could improve vertical deformation in a better way, whose efficiency became smaller along with weld spacing of geocell getting larger within a certain range. Besides, specification of the filler also imposed effects onto the reinforcement efficiency, where filler with larger particle diameter brought about better reinforcement effects. The experimental results demonstrated rationality and effectiveness of structure layer of geocell reinforced with macadam and provided staff members responsible for civil engineering construction with reference on selecting the foundation reinforcement scheme.
\end{abstract}

Keywords: Geocell, loaded-plate tank, geocell filler, load, vertical displacement, vertical deformation.

\section{INTRODUCTION}

Along with development toward modernization, largescale construction has been flourished in China. As scale of the construction getting larger and larger, building load continued to grow, which produced higher-level requirements to the foundation. When large combination of loads are generated by the structure or soil of the foundation is relatively weak that it can't be taken as the natural foundation, property of the foundation shall be improved with foundation reinforcement methods and reinforcement structures to enhance carrying capacity, increase stability and reduce foundation deformation and embedded depth of foundation [1]. On the aspect of foundation reinforcement, reasonable selection for foundation reinforcement structure and scheme will not only affect safety and use of the building, but also greatly influence construction period, project cost and etc. Therefore, growing attention has been given to the foundation reinforcement. To promote and develop various foundation reinforcement, structures and methods play a significant role in improving foundation treatment and ensuring building safety $[2,3]$. There are many factors influencing stability of the foundation reinforcement structure including internal ones and external ones. Internal factors refer to types of the foundation base.

*Address correspondence to this author at College of Municipal and Bridge Engineering, Inner Mongolia Technical College of Construction, Inner Mongolia 0100704, China; Tel: +8613820199918;

E-mail: guochaolu@163.com
Each type of base structure has its own advantages and disadvantages. In bringing supporting capacity into play, upper part of the building structure will impose different degrees of impact [4]. External factors are as follows: firstly, original geology of the foundation such as soil quality, geologic structure and hydrologic conditions; secondly, design scheme of the upper structure, where different construction intentions can lead to different upper structures and loads, thus deformation at different levels will be formed under different pressures generated from lower base; thirdly, stability of the reinforcement structure is subjected to the reinforcement method, technical level of construction and proficiency of construction personnel for applying the method and technology [5].

In a broad sense, civil engineering material refers to all the construction materials used in buildings and structures including a variety of raw materials, semi-finished and finished products, such as clay, quicklime, concrete and etc.; In a narrow sense, it refers to materials directly used to constitute buildings and structures, such as concrete, cement, steel bar, clay brick, glass and etc. [6]. Civil engineering materials shall meet the requirements on technical performance of buildings and structures, which can withstand influence of the surrounding environment and erosion of the harmful media, ensure a reasonable service life of buildings and structures, while can't cause hazards to the surrounding environment. Geocell is made of reinforced HDPE sheet, acting as a commonly used engineering material in civil engineering construction, which is used in a structure of 3D mesh grid chamber under high-strength welding $[7,8]$. The reason why 
Table 1. Geocell specification.

\begin{tabular}{|c|c|c|c|c|c|c|}
\hline Project & Stretching & Stretching & Height & Height of Weld Spacing & Thickness of Sheet & Mass per Unit \\
\hline Type & Width $(\mathrm{cm})$ & Length $(\mathrm{cm})$ & $(\mathrm{mm})$ & $(\mathrm{mm})$ & $(\mathrm{mm})$ & Area $g$ \\
\hline $75-400$ & 600 & 400 & 75 & 400 & 1 & 1700 \\
\hline $150-400$ & 600 & 400 & 150 & 400 & 1 & 3200 \\
\hline $200-400$ & 600 & 400 & 200 & 400 & 1 & 4400 \\
\hline $50-600$ & 600 & 600 & 50 & 600 & 1 & 1650 \\
\hline $75-600$ & 600 & 600 & 75 & 600 & 1 & 2550 \\
\hline $200-600$ & 600 & 600 & 200 & 600 & 1 & 6600 \\
\hline
\end{tabular}

geocell has superior efficacy and thus drawing concerns of the engineering circle shall be talked about from the basic principle. The principle described in foreign literature goes as "a 3D cellular confinement system, which can significantly improve performance of ordinary filling materials in load bearing and worm-eaten control to a wide extent", where the key is just the 3D confinement [9]. However, studies on basic theory of the geocell structure are in a relatively small number. There is lack of studies about deformation mechanism of such a structure under load bearing. Research circles home and abroad are lagging behind in studies on settlement theory relating to this structure. Gravel flexible base has good flexibility, deformation compliance, less possibilities of being affected by water, recycling characters and other features. In this paper, geocell was used to reinforce the macadam base, which could enhance bearing capacity of the primary level under wheel load and reduce the layer-plastic deformation, so that we can conduct experiment on loaded plate to test total deformation of the reinforced structure with geocell, analyze impacts of geocells in different sizes, different fillers and different lower-bearing-layer modulus onto bearing capacity and reinforcement effect of the macadam structure layer for reinforcement, and figure out reinforcement mechanism of the geocell with deformation conditions of cell wall, which provided staff members responsible for civil engineering construction with reference on selecting the foundation reinforcement scheme.

\section{MATERIAL \& METHOD FOR EXPERIMENT}

1) Geocell is built by HMP (high molecular polymer) bars under ultrasonic welding (under added pressure, transmit HF vibration wave onto surface of two objects to be welded, realizing fusion between the molecular layer with mutual frication of those two objects) or weaved adapting pieces.
Geocells involved in this paper are purchased from Taian Ningtai Engineering Material Co., Ltd, whose product type and specifications conform to GB / T19274-2003, where the parameters are shown in Table $\mathbf{1 .}$

Geocell could improve strength of the composite body made up of fillers and geocell, mainly by providing powerful lateral restriction and sidewall friction. Weld spacing and height of the cell are closely related to lateral restriction and sidewall friction provided by geocell.

2) Macadam Macadam/gravel selected for this paper is the christmatite purchased from Guangdong Shenzhen Anju Garden Landscape Quarry with sizes ranging from $0 \mathrm{~mm}$ to $30 \mathrm{~mm}$. Macadam at different sizes were divided into three groups including group A under the range of $0-10 \mathrm{~mm}$, group B under the range of 10-20 mm and group C under the range of $20-30 \mathrm{~mm}$, where fluffy density and compacted density were calculated in accordance with literature [13] respectively going as $1.45 \mathrm{~g} / \mathrm{cm} 3$ and $1.2 \mathrm{~g} / \mathrm{cm} 3,1.18 \mathrm{~g} / \mathrm{cm} 3$ and $1.6 \mathrm{~g} / \mathrm{cm} 3,1.3 \mathrm{~g} / \mathrm{cm} 3$ and $1.25 \mathrm{~g} / \mathrm{cm} 3$.

In this paper, loaded-plate experiment has been applied to simulate load bearing capacity and deformation conditions of the reinforced structure layer with geocell under wheel load. The loaded-plate tank was welded by $2 \mathrm{~cm}$ steel plate in the specification of $0.2 \mathrm{~m} * 0.2 \mathrm{~m} * 0.08 \mathrm{~m}$. Concrete in the thickness of $15 \mathrm{~cm}$ was laid down on bottom of the tank, where the maximum load of the coagulate concrete was measured as $149 \pm 27 \mathrm{KN}$. Maximum load of the tank rack was $357 \pm 41 \mathrm{KN}$. Hoisting jack with hydraulic pressure gauge was used to apply load onto the loaded plate for experiment. Procedures: Lay down media with corresponding parameters, vibrate, exert pressure, measure deformation and spring back.

Total deformation, plastic deformation and deformation of the cell wall of the structure layer of geocell reinforced 

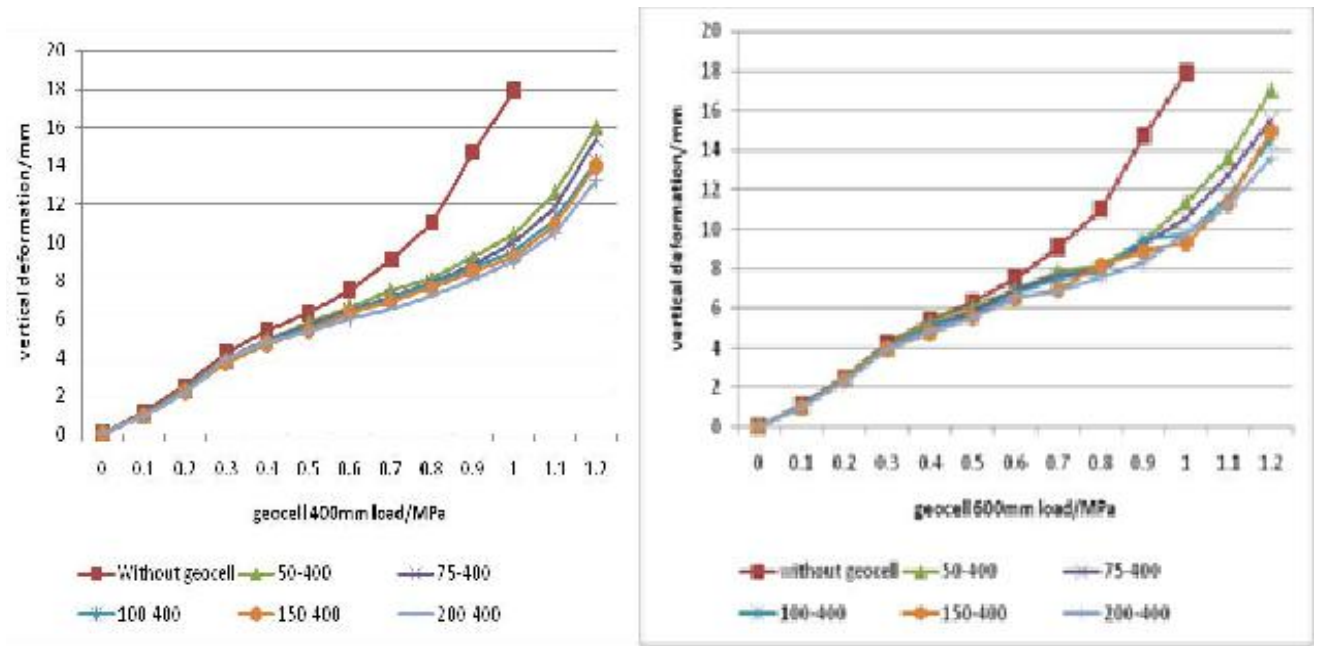

Fig. (1). Relationship between load and displacement of structure layer under the same weld spacing and different cell heights.

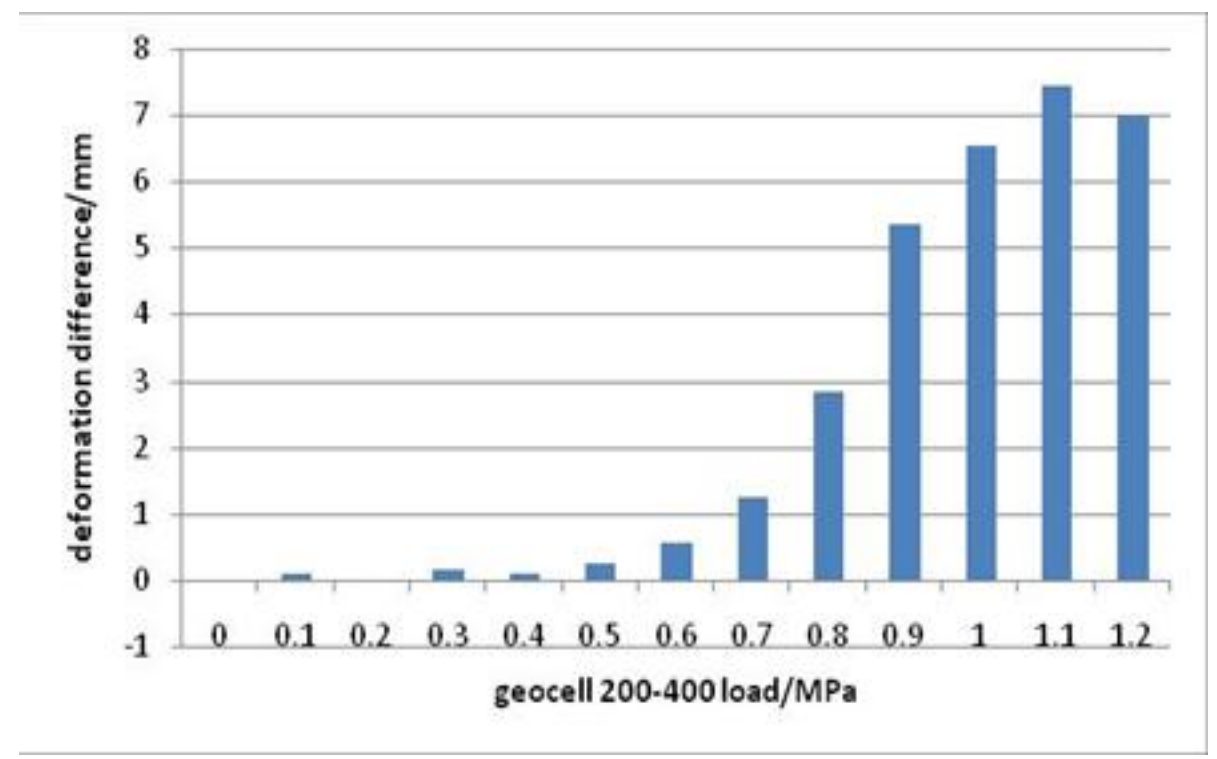

Fig. (2). D-value of vertical deformation of the structure layer (200-400) before and after reinforcement.

with macadam under different sizes of cells, different fillers and different lower bearing-layer modulus have been tested out by the rigid bearing-plate experiment. We analyzed changes of bearing capacity and anti-deformation capacity of the reinforced macadam structure layer before and after the reinforcement treatment for geocell, as well as impacts of cell sizes, fillers and lower-bearing-layer modulus onto bearing capacity and reinforcement effect. Deformation amount of the cell wall inside the structure layer under load has been measured with strain foil, by which we analyzed reinforcement mechanism of the geocell.

\section{RESULT}

The structure layer of geocell reinforced with macadam is mainly composed of macadam filler and geocell. Studies have shown that different cell sizes, different fillers and some other factors would impose some effects onto bearing capacity and reinforcement effect of the structure layer. Loaded-plate experiments under different geocell specification and fillers have been conducted for this paper as quantitative analysis for impacts mentioned above. Heights of geocells used for this paper are respectively $50 \mathrm{~mm}, 75 \mathrm{~mm}, 100$ $\mathrm{mm}, 150 \mathrm{~mm}$ and $200 \mathrm{~mm}$. Weld spacings of the cells are respectively $400 \mathrm{~mm}$ and $600 \mathrm{~mm}$. There are 9 kinds of geocells for loaded-plate experiments in total. Thickness of cell was $1 \mathrm{~mm}$.

To study the structure layer of geocell reinforced with macadam, we took geocell sizes as the starting point to analyze relevant impacts onto bearing capacity and reinforcement effect. Relationship between load and displacement of the structure layer under the same weld spacing and different cell heights is shown in Fig. (1). Relationship between load and displacement of the structure layer under the same cell height and different weld spacing is shown in Fig. (2). 


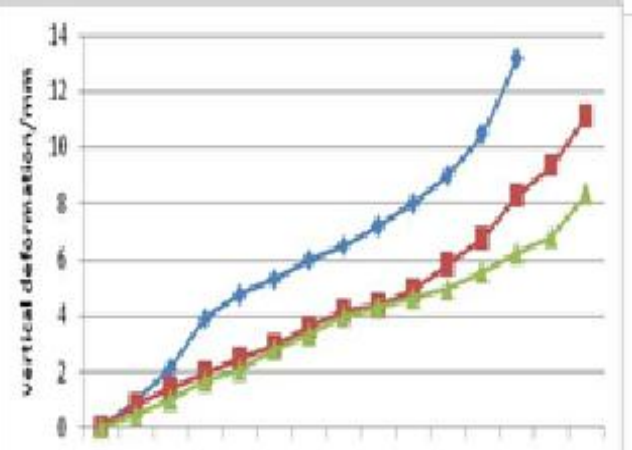

00102030.40506070809111121314 gecellabo-400 load/Nha

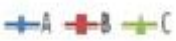

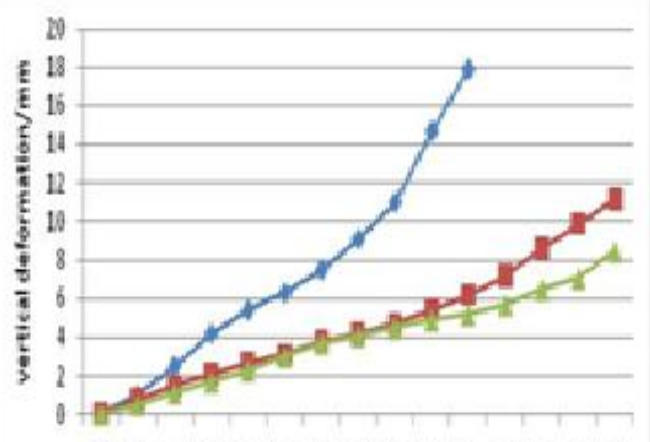

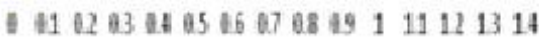

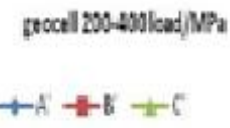

Fig. (3). Relationship between load and vertical deformation of structure layers with various fillers in the geocell (200-400).

We can see in the figure above that structure layer of geocell reinforced with macadam, regardless of the cell sizes, could improve vertical deformation in a better way, where vertical deformation has been significantly reduced under the same load. Taking vertical deformation before and after reinforcement treatment by geocell with weld spacing of $400 \mathrm{~mm}$ as an example, we can see that only little difference has been shown between structure layers of geocell reinforced with or without macadam under different specifications as external load less than $0.25 \mathrm{MPa}$, that is, the macadam-filled structure can meet the bearing requirements as external load less than $0.25 \mathrm{MPa}$. When the external load is larger than $0.25 \mathrm{MPa}$, vertical deformation of the structure layer without geocell shows rapid growth. Relationship between D-value of vertical deformation of the 200-400 structure layer before and after reinforcement and loads is shown as follows.

As the load increases, D-value of vertical deformation of the structure layer before and after reinforcement keeps growing, indicating that geocell provides good reinforcement effect for the macadam structure layer, where effective reduction has shown in the vertical deformation under the same load.

As geocell providing powerful friction drag and lateral restriction for its internal filler, fillers in different materials and different specifications of the filler will produce different impacts onto bearing capacity and reinforcement effects of the structure, which can be found out during studies for impacts of external load by using the structure layer of geocell reinforced with macadam. Groups A, B and C of christmatite have been used for this paper as filling materials, where diameter distribution goes as $0-10 \mathrm{~mm}, 10-20 \mathrm{~mm}$ and $20-30 \mathrm{~mm}$, and macadam structure layer with the same material without being reinforced by geocell has been taken as the control group. Taking geocell in the specification of 200400 as the object of study, relationship between loads and deformation of three macadam groups and control group under the effect of loaded plate is shown in Fig. (3).

Note: A', B' and $\mathrm{C}^{\prime}$ are the results of group A, group B and group $\mathrm{C}$ compared with the group without reinforcement.
We can see from the figure above that reduction to some extent of vertical deformation has been shown by structure layers of geocell (200-400) before and after reinforcement, where vertical deformation gradually decreases along with particle size of macadam getting larger and group A (i.e. 0-5 $\mathrm{mm}$ macadam) shows the maximum reduction of vertical deformation. In addition, same results can be obtained by geocells at different specifications.

\section{CONCLUSION}

As an important segment during work progress of civil engineering, foundation reinforcement concerns about safety and use of the building. Stability of foundation reinforcement structure is subjected to many factors. To do a better job for foundation reinforcement, various factors shall be taken into consideration, investigation at earlier periods and works at later period shall be done well, reinforcement technology and construction level of staff members shall be improved. There are various technologies for reinforcement. We shall select one or more than one treatment methods according to characteristics, geological conditions, ambient conditions and execution conditions of the reinforcement project, so that we can obtain the best possible technical and economic benefits. For the structure, permanent deformation joint shall be set or pouring belt after the construction shall be applied to maximize the stability of foundation. Flexible base of macadam can well adapt to uneven deformation of the roadbed and reduce moisture loss. However, macadam base has disadvantages including large plastic deformation, lack of bearing capacity and etc. Reinforcement treatment for macadam base with geocell has been adopted in this study to prove effectiveness and practicality of such a method in foundation reinforcement during work progress of civil engineering. For this paper, we conducted research on bearing capacity of the structure layer reinforced with macadam and factors influencing the bearing capacity. Analysis in details has been done by establishing physical model, setting experimental technique and analyzing deformation of macadam structure layer in the loaded-plate experiment. Experimental 
results show that geocells at different specifications, fillers at different specifications and materials will impose certain impacts onto bearing capacity and reinforcement effect of the structure layer. Structure layer of geocell reinforced with macadam could improve vertical deformation in a better way, whose efficiency became smaller along with weld spacing of geocell getting larger within a certain range. Besides, specification of the filler also imposed effects onto the reinforcement efficiency, where filler with larger particle diameter brought about better reinforcement effects.

In our opinion, however, scope of this paper is relatively narrow with certain limitations. We suggest that plastic deformation of the reinforcement structure layer shall be taken as the design target, various parameters shall be restricted and design method shall be proposed for reinforcing structure layer with macadam in the later part of this study. And then, we shall verify the reasonableness of geocell structure layer reinforced with macadam by building trail road and observation, based on which we can consummate and correct the indoor experimental results, propose design method, construction technology and quality control measures for such a structure.

\section{CONFLICT OF INTEREST}

The author confirms that this article content has no conflict of interest.

\section{ACKNOWLEDGEMENTS}

This work was supported by Territorial resources survey items (No. 1212011220187) and National Natural Science
Foundation of China (No. 40534021); Guangxi Natural Science Fund innovative research team project (2012GXNSFGA060001); Project foundation of Guangxi Key Laboratory of geotechnical mechanics and Engineering (12-A-01-01).

\section{REFERENCES}

[1] X. Z. Wang and W. H. Zheng, "Study on Application of Geocell Flexible Spear Plate at Road-Bridge Transition Section", Railway Standard Design, vol. 12, no. 1, pp. 5-8, 2009.

[2] Ministry of Communications, Roadbed Construction Specifications (JTGF10-2006). Beijing: PRC Ministry of Communications, 2006.

[3] S. H. Zhou, Y. H. Yang, and S. X. Wang, "Analysis on Influencing Factors of Structure Excavation for Settlement of Surrounding Earth Surface", Geotechnical Foundation, vol. 4, pp. 38-41, 2008.

[4] H. P. Lai, Y. L. Xie, and X. H. Yang, "Study on Stability of Shallow Layer of Expansive Soil Slop in Xihan Highway", Journal of Wuhan University of Science \& Technology, vol. 32, no. 1, pp. 2933, 2010 .

[5] Y. Chen, J. Fang, and J. F. Zhao, "Experimental Study on CF-net Anti- scouring Indoor Model on Side Slope of Highway", Journal of Rock Mechanics \& Engineering, vol. 29, no. 1, pp. 2936-2942, 2010.

[6] Railway institute of General technology, "The design and construction handbook of mixing piled foundation (machine mixing)", M.S. thesis, Tokyo: Railway Institute of General Technology, 2001.

[7] M. H. Zhao, Y. B. Deng, and M. H. Yang, "Calculation and Experimental Study on Pile-soil Stress Ratio of Macadam-column Composite Foundation under Load of Road Embankment", Soil \& Rock Mechanics, vol. 30, no. 9, pp. 2623-2628, 2009.

[8] S. Y. Liu, Y. L. Yi, and Z. D. Zhu, "On-site Comparative Trial for Reinforcement of Highway Soft-soil Foundation with Bidirectional Mixing Pile", Journal of Rock Mechanics \& Engineering, vol. 27, no. 11 , pp. 2272-2280, 2008

[9] U. S. Okyay and D. Diasa, "Use of lime and cement treated soils as pile supported load transfer platform", Engineering Geology, vol. 114 , no. 1-2, pp. 34-44, 2010.

(C) Lu et al.; Licensee Bentham Open.

This is an open access article licensed under the terms of the Creative Commons Attribution Non-Commercial License (http://creativecommons.org/licenses/bync/4.0/) which permits unrestricted, non-commercial use, distribution and reproduction in any medium, provided the work is properly cited. 